\title{
Tumor formations in scleractinian corals
}

\author{
Y. Loya ${ }^{1}$, G. Bull ${ }^{2} \&$ M. Pichon ${ }^{2}$ \\ ${ }^{1}$ Department of Zoology, Tel Aviv University; Tel Aviv, Israel \\ ${ }^{2}$ Department of Marine Biology, James Cook University of North Queensland; \\ Townsville, Queensland 4811, Australia
}

\begin{abstract}
A highly localized incidence of skeletal malformations (tumors) in the scleractinian corals Platygyra pini and $P$. sinensis on an inshore fringing reef at Cockle Bay, Magnetic Island within the Great Barrier Reef province is reported. These tumors are typified by a localized area of increased growth rate resulting in roughly circular protuberances extending up to $4.5 \mathrm{~cm}$ above the colony's surface. In both species, similar proportions of their populations carried tumors $(24.1 \%$ in P. pini and $18.7 \%$ in $P$. sinensis). Larger colonies ( $>80 \mathrm{~cm}$ in diameter) are at least 7 times more likely to possess tumors than smaller colonies $(<40 \mathrm{~cm}$ in diameter). X-radiographs of the skeletal malformations indicate a point of origin, presumably from a single budded polyp with subsequent, localized, accelerated growth. The mean radial growth rate of the tumorous area was $29 \%$ greater than that of the surrounding normal regions. In contrast to the normal tissue, the tumorous tissue exhibited proliferation of cells, atrophied gastrodermal cells and mesenterial filaments which were larger and disordered in structure. The environmental conditions at Cockle Bay are relatively extreme with high turbidity, periodic exposure of the reef flat, abrupt changes in salinity during the wet season and mechanical damage to corals caused by unpredictable cyclonic storms. It is suggested that a combination of environmental stresses coupled with an injury inflicted on the corals are possible stimuli that initiate the development of these abnormal growth through either bacterial attack or the development of an aberrant polyp during tissue repair.
\end{abstract}

\section{INTRODUCTION}

In the present study we report the occurrence of skeletal malformations in the massive meandroid coral Platygyra (Faviidae), on an inshore fringing reef in the Great Barrier Reef province. Skeletal malformations have been previously described in some scleractinian corals as neoplasms (Squires, 1965a, b) or tumors (Cheney, 1975). Others have been shown to be growth reactions to invasion by parasites (Cheng \& Wong, 1974), endozoic animals (Patton, 1976) or contact with adjacent corals (Hildemann et al., 1975). However, some of the structures described in the literature as tumors are actually hyperplasia or unusual proliferations of typical cellular components in response to injury or parasitic invasion (Sparks, 1972). Tumor-like growths had been observed previously in Scleractinia from the Pacific, although the etiology of these growths has remained largely obscure (Squires, 1965a, b; White, 1965; Soule, 1965; Cheney, 1975).

The abnormal growth formations described here appear on the surface of the colony as roughly circular protuberances ("bumps") extending above the colony's surface (Fig. 1). We have termed these bumps as tumors, since we consider that they resulted from an independent localized acceleration of tissue-growth.

Reports of neoplasms in coelenterates and particularly in scleractinian corals are 


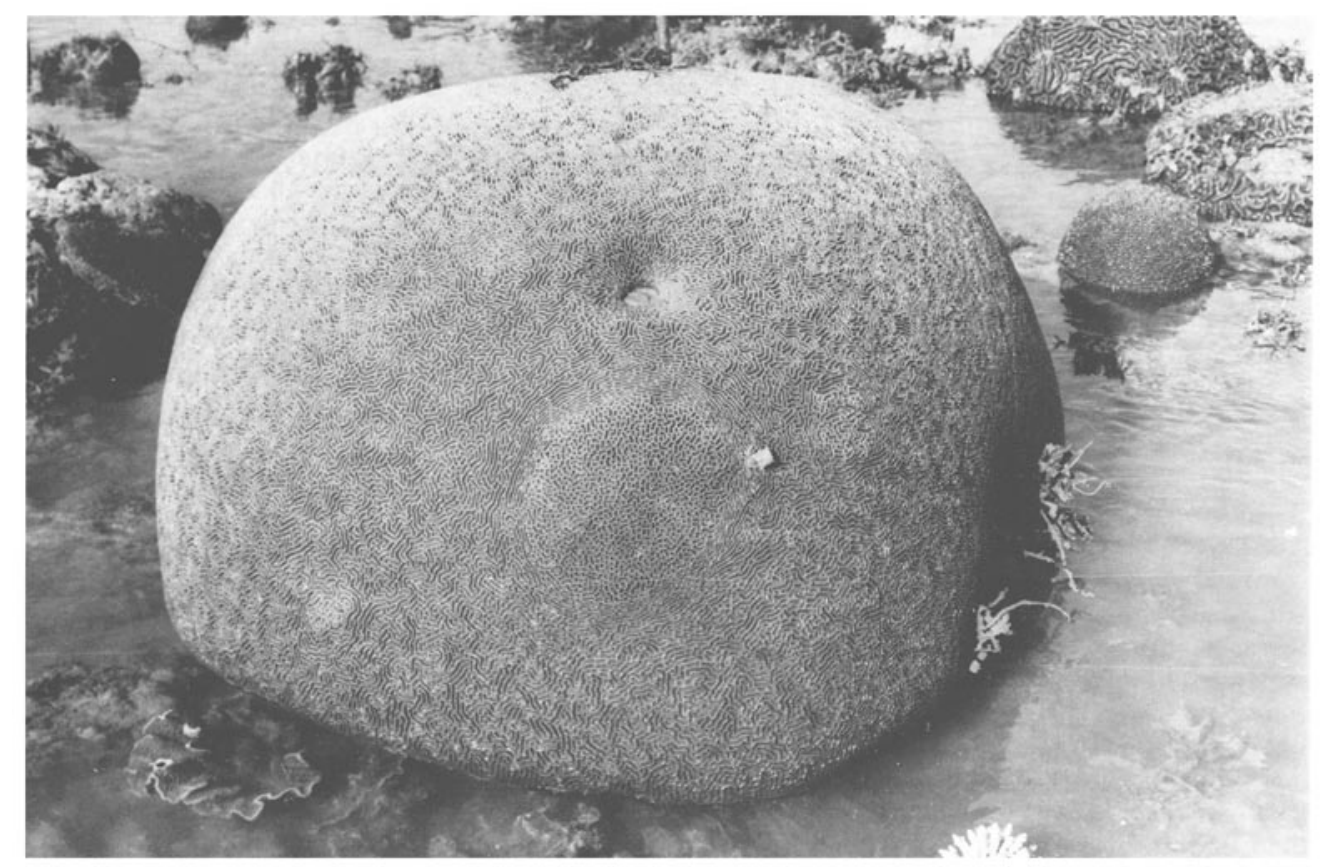

Fig. 1. A colony of Platygyra sinensis (approximately $90 \mathrm{~cm}$ in diameter) emersed at spring low tide. A tumor of approximately $200 \mathrm{~cm}^{2}$ ( $1 \%$ of the colony's surface area) can be seen in front of the colony

infrequent and their authenticity has often been questioned. Squires (1965a) interpreted the presence of 3 abnormal corallites from the only known specimen of Madrepora kauaiensis as neoplasia. Since tissue was not preserved, the assumption was derived solely from skeletal examination. White (1965) and Soule (1965) provide alternative interpretations to Squires' suggestions. They suggested that the abnormal corallites were produced in response to some sedentary virus, bacterium or invertebrate (White, 1965) or individual of another species growing attached to the colony (Soule, 1965). Squires (1965b) disagreed with the latter interpretation because examination of the exterior and interior of the specimen showed no evidence of overgrowth by another organism. Additionally, the skeletal elements of the abnormal corallites were organically connected to the colony and his interpretation was that they have been formed asexually by polyps lower on the branch.

The only other report we are aware of concerning tissue tumors in scleractinian corals was given by Cheney (1975) who described atypical growths ("tumors") of the coral Acropora formosa in shallow and protected areas of the reefs of Guam. He interpreted these growths as true neoplasms, and not just hyperplastic responses to macroscopic organisms. Cheney subjected large numbers of the Acropora tumors to microscopic examination, but did not find any foreign etiological agent.

Abnormal growth proliferations in coelenterates have been reported following damage or invasion to polyps. Kaufman (1980) observed that gall-like nodules were formed on certain Acropora species in response to predation damage by damsel-fishes. It 
is not yet known whether the growth of the Acropora gall occurs solely in response to the damage caused by grazing, or if another etiological agent (e.g. a secondary invader) is involved.

A different sort of growth aberration in scleractinian corals in response to larval trematodes was described by Cheng \& Wong (1974). They reported the occurrence of pinkish nodules $3-5 \mathrm{~mm}$ in diameter, encysted in polyps of the coral Porites sp, in Hawaii. The nodules extended 1-2 $\mathrm{mm}$ above the surface of the colony and contained trematode metacercariae of Plagioporous $\mathrm{sp}$. The only histological alterations observed were compressed epithelial cells and pavemented cyst walls, in the few cases when the cyst had apparently perforated the gastrovascular cavity.

None of the abnormal growth proliferations, described so far in the literature for scleractinian corals, resembled the skeletal malformations encountered in Platygyra colonies at Cockle Bay. Our initial research objectives were to quantify the occurrence of these tumors on corals in the study area, study possible differences between the abnormal growths and adjacent normal colony parts, and attempt to detect possible causative agents to this phenomenon.

\section{STUDY AREA AND METHODS}

The study was carried out on the reef flat of Cockle Bay, Magnetic Island $\left(19^{\circ} 9^{\prime} \mathrm{S}\right.$, $146^{\circ} 50^{\prime} \mathrm{E}$ ), a high continental island in front of Cleveland Bay, approximately $8 \mathrm{~km}$ north of Townsville. (For map of the Townsville area showing Magnetic Island and surrounding area, see Morrissey, 1980.)

Environmental factors at Cleveland Bay and nearby bays were summarized by Collins (1978), Morrissey (1980) and Bull (1982). Monthly means of surface seawater temperatures vary from $21.8^{\circ} \mathrm{C}$ in July (winter) to $31.2^{\circ} \mathrm{C}$ in January (summer) resulting in an annual range of $9.4^{\circ} \mathrm{C}$ (Kenny, 1974). Reef flat areas show greater variation in diurnal seawater temperature reaching $14^{\circ} \mathrm{C}$ in mid-winter (Morrissey, 1980). Grigg (1972) recorded an annual variation in salinity from $27.1 \%$ to $37.1 \%$ for one station in Cleveland Bay. During periods of maximum rainfall (January-February) salinities in the range of $17.0 \%$ to $36 \%$ were measured by Collins (1978) in Nelly Bay, situated close to Cockle Bay. Water turbidity (Secchi disc visibility) in Nelly Bay varies annually from $0.8 \mathrm{~m}$ to $6.5 \mathrm{~m}$, with an average of $1.8 \mathrm{~m}$ (Collins, 1978). The tidal regime for Cleveland Bay is semi-diurnal with diurnal inequality. Spring tides alternate regularly with neap tides. Mean spring tide range is $2.5 \mathrm{~m}$ and the mean neap tide range is $0.8 \mathrm{~m}$. The reef flat at Cockle Bay emerges periodically for 3 to $4 \mathrm{~h}$ daily during spring low tides only (Fig. 2). There is a seasonal change in the time of occurrence of the daily low-water, during spring tides: in summer they occur at night and in winter during the afternoon.

We examined all colonies with a diameter greater than $25 \mathrm{~cm}$ for presence of skeletal malformations in an experimental plot $(35 \times 20 \mathrm{~m}$ area) on the reef flat. Sizes of colonies were measured as maximum horizontally projected length (Lc), and a width (Wc) which was measured perpendicular to the maximum length. Geometric mean diameters of colonies $(\overline{\mathrm{D}} \mathrm{c})$ were calculated as $\overline{\mathrm{D}}_{\mathrm{C}}=(\mathrm{Lc} . \mathrm{Wc})^{1 / 2}$. Surface dimensions of the tumorous areas were measured in a similar manner and geometric mean diameters of the tumors ( $\mathrm{t}$ ) calculated as $\overline{\mathrm{D} t}=(\mathrm{Lt} . \mathrm{Wt})^{1 / 2}$. The orientations of the tumors on the colonies were measured in a horizontal plan, by compass angles. 


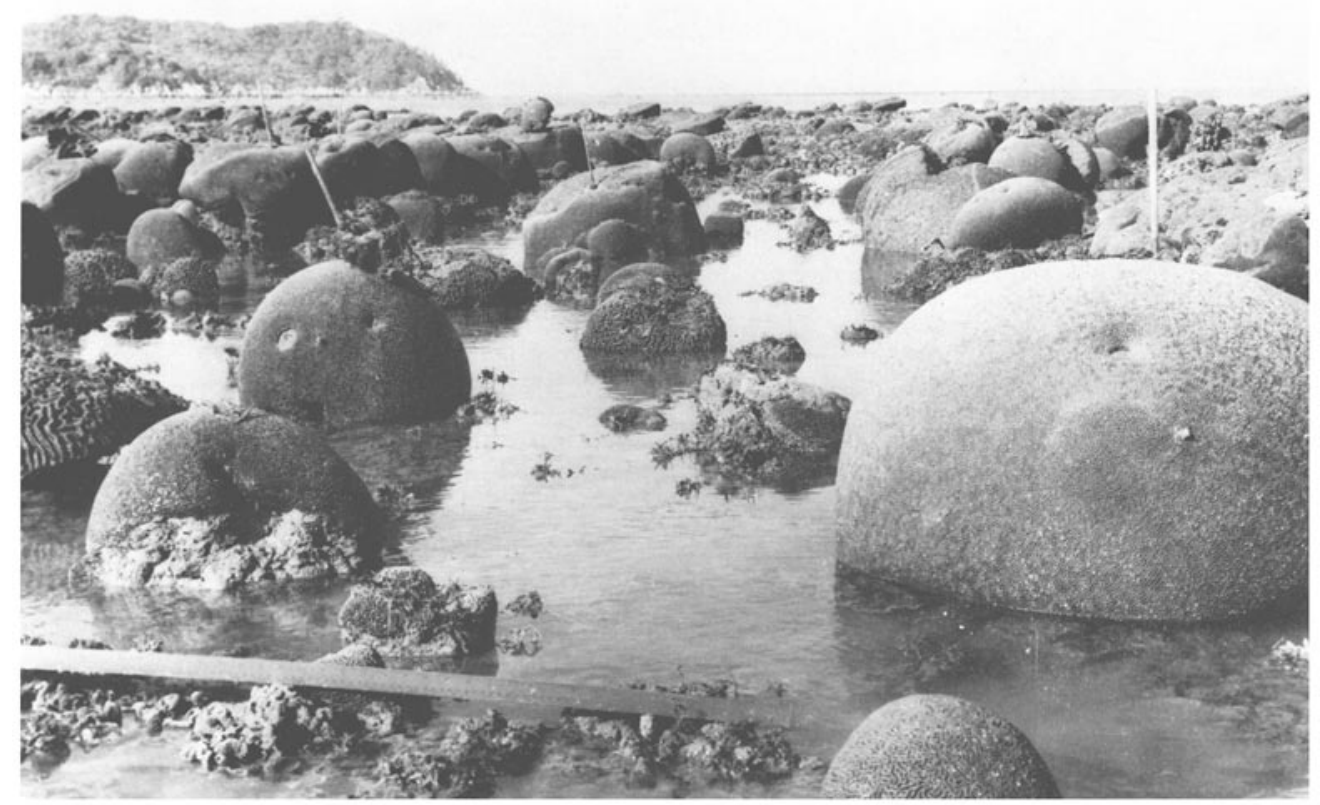

Fig. 2. Emersion of reef-flat during spring low tide at Cockle Bay, Magnetic Island. Note the flat, dead tops on some of the colonies. Right-colony with a tumor; second colony from left shows experimental "extensive lesion"

The gross morphology of the skeletal malformations is described on the basis of observed external skeletal features and X-radiographs of skeletal sections. The Xradiographs were done with a Shimadzu $\mathrm{Imf}$ capacitor discharge X-ray unit, using Kodak MinR or Fuji MI-NC films. Sections of 1.0 to $1.5 \mathrm{~cm}$ thickness cut radially from the colonies gave good definition of the annual bands and the orientation of calice axes.

Material for microscopic examination was fixed in $4 \%$ seawater formalin for $24 \mathrm{~h}$, rinsed for half an hour and transferred to $70 \%$ alcohol for further studies. The skeleton was decalcified using formic acid and sodium citrate in distilled water (see Rinkevich \& Loya, 1977 for details). The remaining tissue was paraffin embedded, sectioned at $7 \mu \mathrm{m}$ and stained with hematoxylin and eosin or Gomori trichrome.

Experimental lesions were made on several coral species in the experimental plot, in order to test the possibility that the abnormal growths developed as a result of mechanical damage. We made 2 series of circular lesions on different colonies. In both series, the tissue and skeleton were damaged using a hammer and chisel. The first series consisted of 12 to $140 \mathrm{~cm}^{2}$ lesions with average depth of $0.4 \mathrm{~cm}$ ("superficial lesions"). The second series consisted of lesions of similar size, but the average depth of the wound was $1.5 \mathrm{~cm}$ ("extensive lesions").

\section{RESULTS}

The incidence of abnormal growths in populations of Platygyra observed at Cockle Bay, Magnetic Island is highly localized. We have not observed such a high occurrence 
of tumors in nearby reefs or elsewhere during surveys of a large number of reef flats of the Great Barrier Reef. The tumors extend up to $4.5 \mathrm{~cm}$ from the colony's surface. The orientation and length of the meanders (valleys) compared with adjacent healthy areas is distinctly altered (Figs 3,4). The meanders within the tumors are usually shorter with smaller numbers of mouths per valley (Fig. 3). In some cases, the thecal walls within the

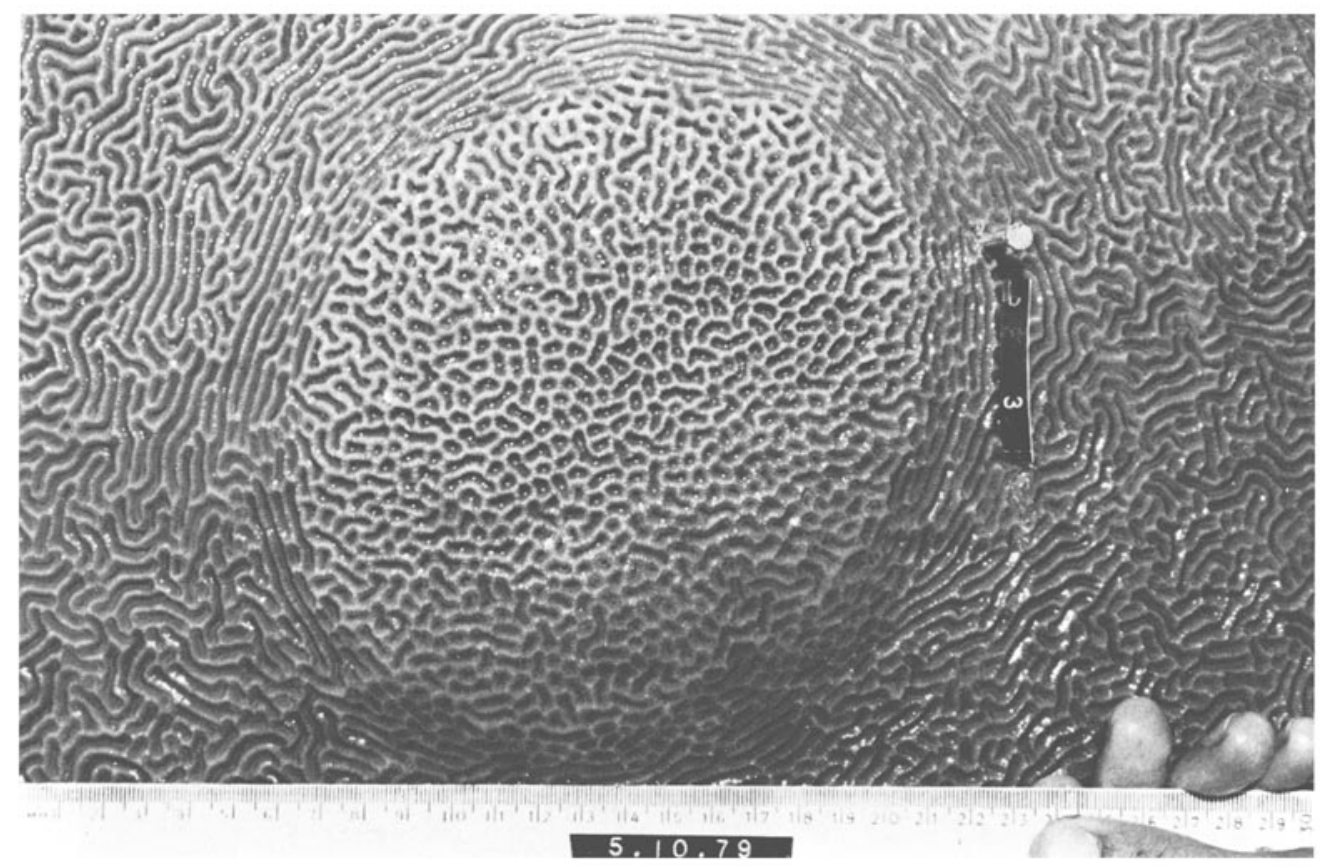

Fig. 3. Close-up of a tumor from the colony shown in Figure 1. Note the change in length and orientation of meanders (valleys) within the tumorous area compared with its edges and adjacent normal areas

tumorous area are much thicker than normal thecae (Fig. 5). The valleys on the boundary between the tumorous area and adjacent normal area are condensed and differ in their morphology both from the abnormal and normal meanders. Although valleys are not continuous across the boundary between abnormal and normal areas, separation is only by a normal thecal wall. Veron et al. (1977) indicated that the numbers of mouths or centers per valley are variable in both $P$. pini and $P$. sinensis. Although different in their morphology, the valley growth forms within the tumorous areas and in the normal parts of the colonies, are both within a range acceptable for the species.

The frequency of abnormal growth formations was recorded on all massive corals (with a mean diameter $>25 \mathrm{~cm}$ ) in the experimental plot $\left(700 \mathrm{~m}^{2}\right)$ on the reef flat (Table 1). Of the 7 coral species recorded, we found tumors only in colonies of $P$, pini and $P$. sinensis, with similar proportions of tumors in each (i.e. $24.1 \%$ in $P$. pini and $18.7 \%$ in $P$. sinensis, which had one or more tumors). In both species the average size of colonies with tumors is significantly larger than the average size of colonies without tumors (t-tests, $\mathrm{p}<0.01$ ). 


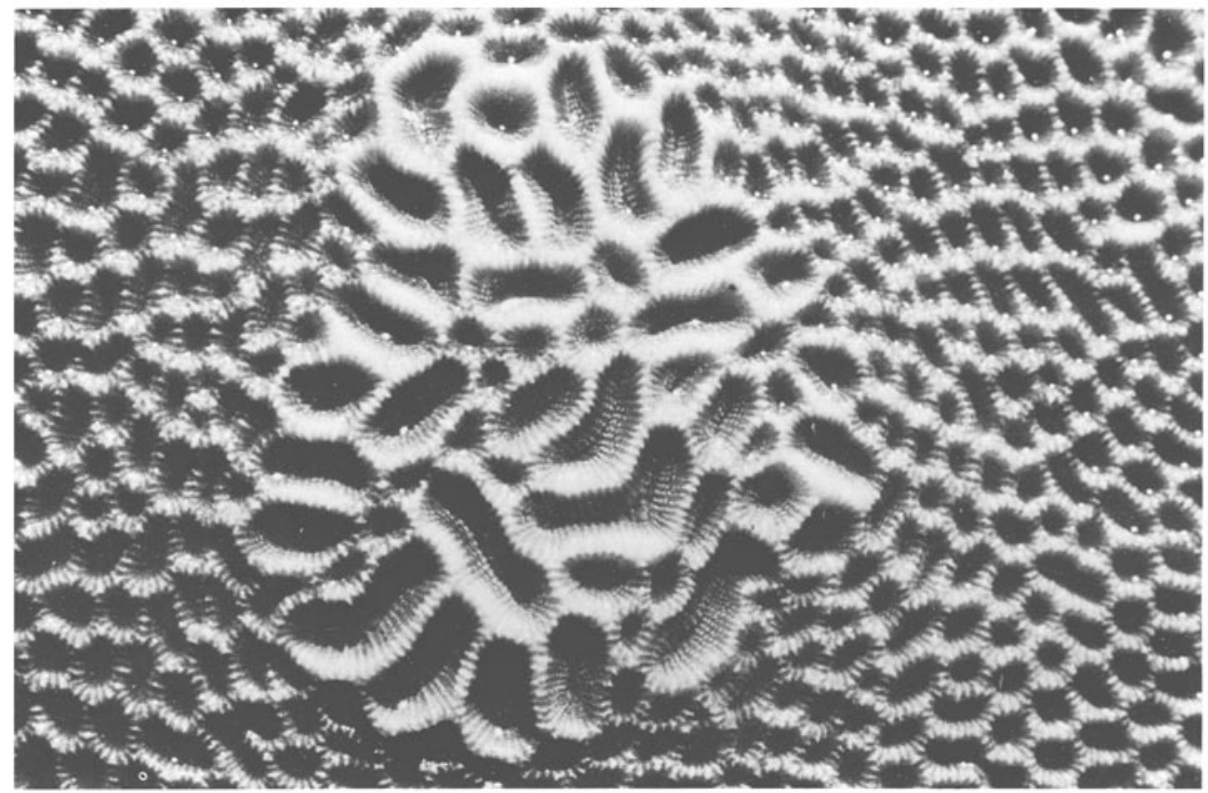

Fig. 4. Close-up of a tumor on a colony of Platygyra pini. Note the unusually thick and large thecal walls of the tumorous area

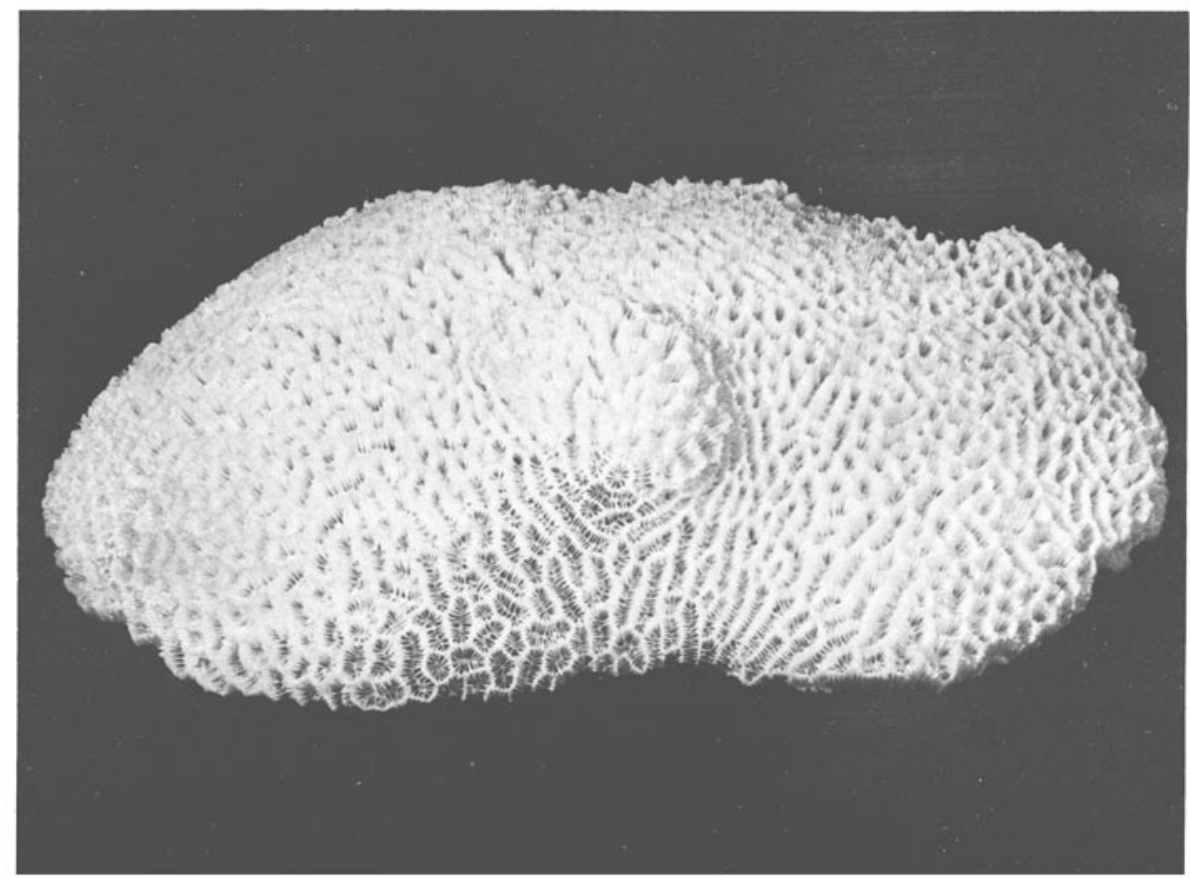

Fig. 5. A bleached skeleton of part of a colony of Platygyra pini. The protuberance on the colony's surface extends $2.5 \mathrm{~cm}$ outwards from the colony 
Table 1. Frequency of skeletal malformations (tumors) in massive corals (with mean diameter $>25$ $\mathrm{cm}$ ) in a $700 \mathrm{~m}^{2}$ reef-flat area (standard deviations of coral sizes are given in parentheses)

\begin{tabular}{|lccccc|}
\hline \multicolumn{1}{|c}{ Species } & $\begin{array}{c}\text { Total No. of } \\
\text { colonies }\end{array}$ & $\begin{array}{c}\text { No. of } \\
\text { colonies } \\
\text { with tumors }\end{array}$ & $\begin{array}{c}\text { Coral size (Dc) in cm } \\
\text { without } \\
\text { tumors }\end{array}$ & $\begin{array}{c}\text { with } \\
\text { tumors }\end{array}$ \\
\hline Platygyrapini & 108 & 26 & $61.3(29.4)$ & $87.3(26.4)$ \\
P. sinensis & 64 & 12 & $48.4(22.9)$ & $67.6(26.4)$ \\
Symphyllia recta & 55 & 0 & $65.2(24.8)$ & - \\
Lobophyllia hemprichi & 5 & 0 & $59.3(24.7)$ & - \\
Porites sp. & 3 & 0 & $74.0(35.0)$ & - \\
Platygyra daedalea & 2 & 0 & $29.5(3.0)$ & - \\
Favia favis & 1 & 0 & 35.0 & & - \\
\hline
\end{tabular}

An analysis of tumor incidence as a function of coral size (geometric mean diameter) is given in Figure 6 for $P$. pini and in Figure 7 for $P$. sinensis. As size increases, colonies with abnormal growths represent an increasing proportion of the total. In both species the highest proportion of tumors was found in colonies of 81 to $100 \mathrm{~cm}$ in diameter. Approximately $50 \%$ of all Platygyra colonies $>80 \mathrm{~cm}$ in diameter have at least one tumor formation. In small Platygyra colonies (25-40 cm diameter), the incidence of abnormal growths is $0 \%$ in $P$. pini and $6.6 \%$ in $P$. sinensis. Thus, larger colonies

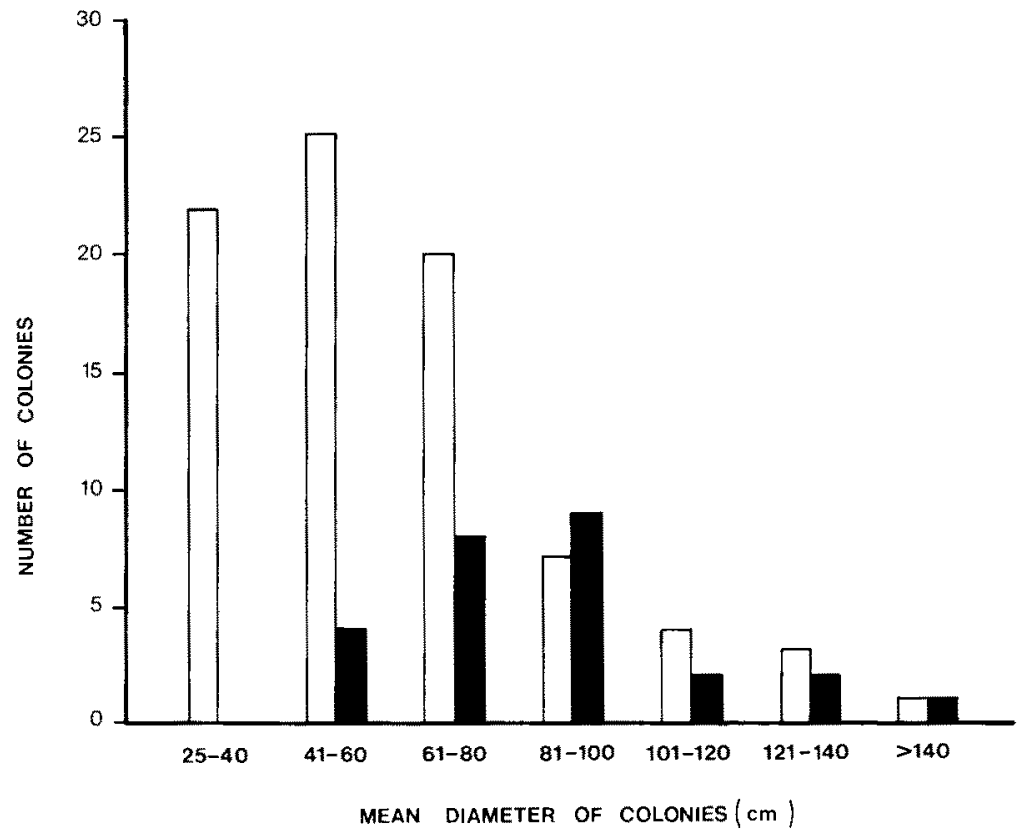

Fig. 6. Frequency of tumor occurrence in different size classes (geometric mean diameter) of Platygyra pini. Black bars represent colonies with tumors. Blank bars represent colonies without tumors 


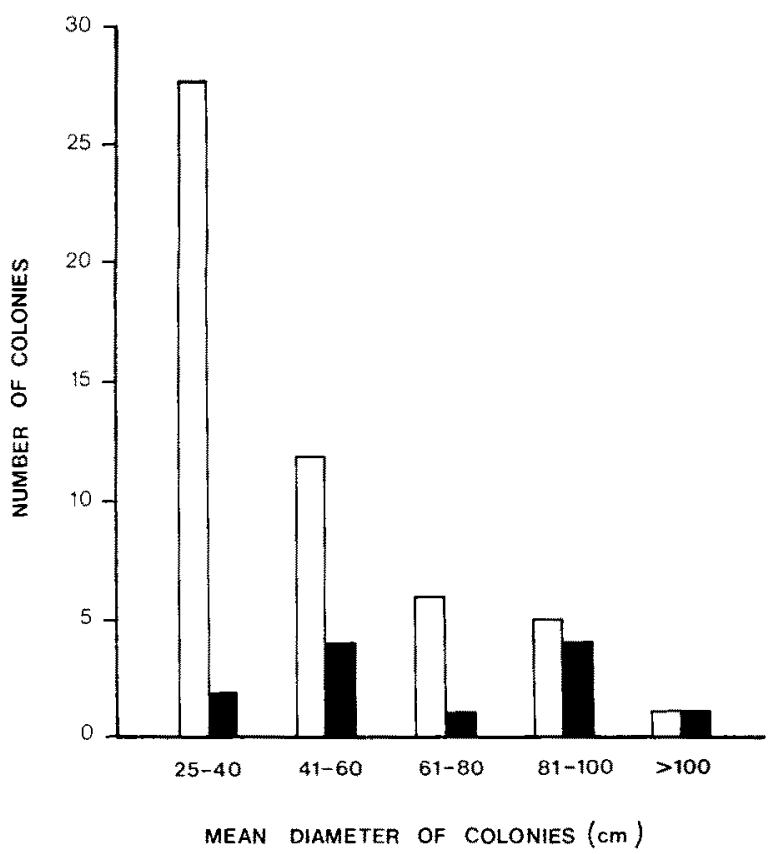

Fig. 7. Frequency of tumor occurrence in different size classes of Platygyra sinensis. See Figure 6 for explanation

( $>80 \mathrm{~cm}$ in diameter) are at least 7 times more likely to possess tumors than smaller colonies $(<40 \mathrm{~cm}$ in diameter). No tumors were detected in very small colonies (e.g. $<25 \mathrm{~cm}$ in diameter). Mean sizes of tumors on $P$. pini were $\overline{\mathrm{D}} \mathrm{t}=11.6 \pm 7.6 \mathrm{~cm}(\mathrm{n}=26)$ and on $P$. sinensis $\overline{\mathrm{D}} \mathrm{t}=13.2 \pm 10.6 \mathrm{~cm}(\mathrm{n}=19)$. Only one tumor per colony was recorded in $P$. sinensis whereas in $P$. pini there were some colonies with more than one tumor (one colony had 4 tumors, 4 colonies had 2 tumors and the rest had 1 tumor each).

There is no significant difference in the average colony size carrying abnormal growths between $P$. pini and $P$, sinensis (t-test, $\mathrm{p}>0.05$ ). Calculation of the ratio between the surface area of the tumor and the surface area of its colony reveals that in $P$. sinensis the tumorous area occupies an average of $1.2 \%$ of the colony's surface area, while in $P$. pini it is only $0.6 \%$. No significant correlation was found between the sizes of tumors $(\bar{D} t)$ and the sizes of colonies $(\bar{D} c)$ on which they occurred.

$\mathrm{X}$-radiographs of the abnormal skeleton and surrounding normal skeleton (Fig. 8) clearly indicate a point origin for the tumor and subsequent localized, accelerated growth. Assuming that the growth bands are annual, as shown for other corals in the Great Barrier Reef (Isdale, 1977) the age of the tumor was estimated by counting the number of dark bands over which the growth increment was measured. The dark (low density) bands of the skeleton occur during the winter, while the light (high density) bands occur during the summer (Isdale, 1977). We have measured skeletal growth rate from point origins of tumors to the extant surface, and compared it with adjacent healthy parts (Table 2). All measurements represent radial growth rates. In all the X-radiographed abnormal skeletons, growth rate was higher than in adjacent normal areas. The 


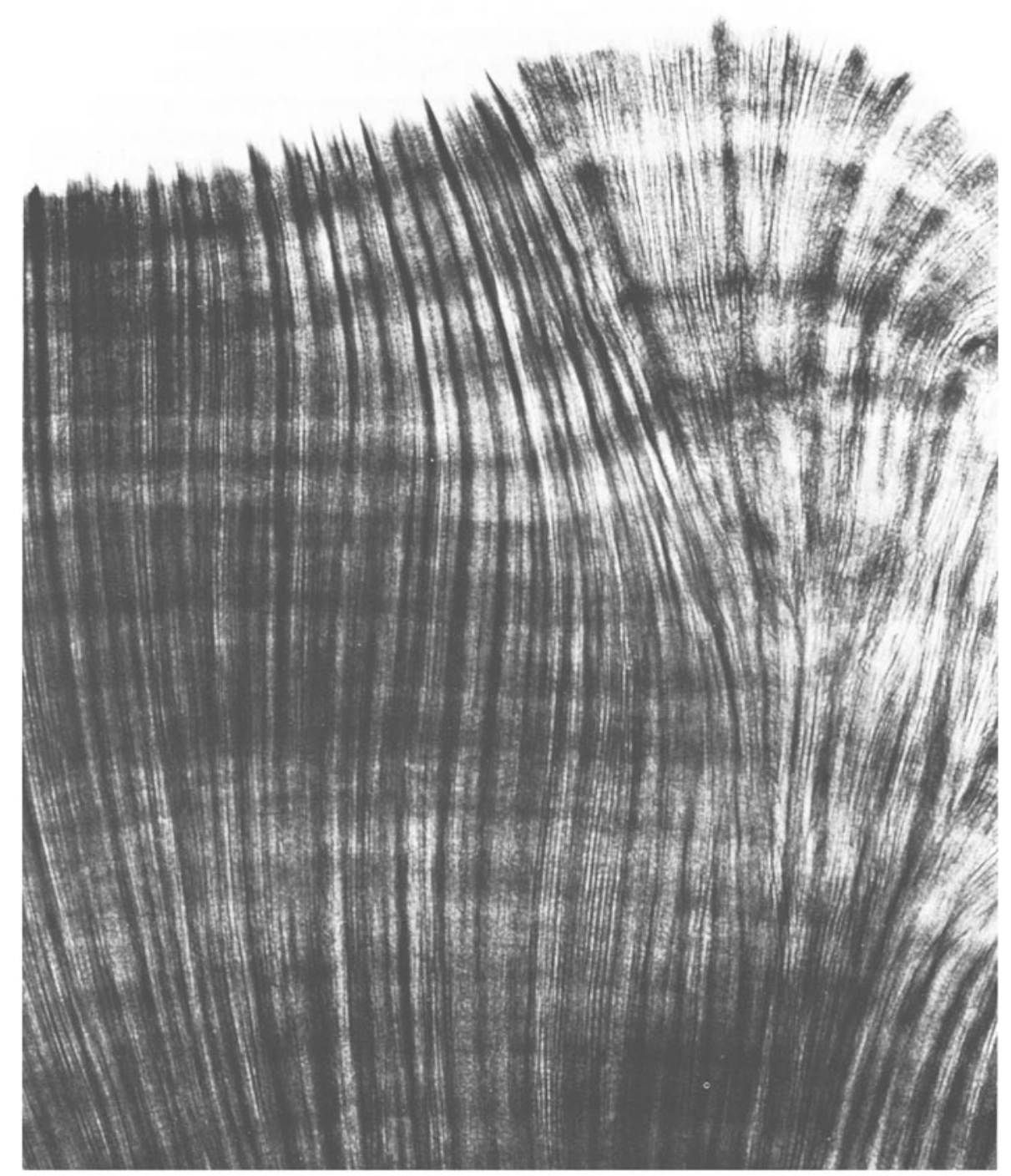

Fig. 8. X-radiograph of a section of Platygyra pini (actual size) with annual growth bands. Normal part of the colony (left); tumorous part (right)

mean radial growth rate of abnormal skeletons was $29 \%$ greater than that of normal areas (range $20-41 \%$, Table 2). Observation of radial lines of calice axes indicate that the tumors also have a greater circumferential growth rate than the rest of their colonies, causing a bunching up of normal calices at the periphery. In none of the X-rayed colonies was there any indication of infaunal invasion, or regrowth after death or damage at the points of origin of the tumors.

Comparison of light microscope sections of tissues from normal and tumorous areas showed proliferation of cells in all parts of the tumorous tissues. The mesenterial 
Table 2. Skeletal growth rate in abnormal areas vs adjacent normal areas of different Platygyra colonies. Age (years) represents the number of anmual growth bands over which the growth increment was measured

\begin{tabular}{|cccc|}
\hline \multirow{2}{*}{ Age (years) } & \multicolumn{2}{c|}{ Radial growth (mm) } & Percent increase in \\
& Normal area & Tumor & growth of tumor \\
\hline 18 & 122 & 167 & 36.9 \\
20 & 127 & 159 & 25.2 \\
10 & 81 & 97 & 19.8 \\
5 & 28 & 34 & 21.4 \\
5 & 36 & 51 & 41.7 \\
\hline
\end{tabular}

filaments appeared larger, more disordered in structure and more branched than the normal ones. The gastrodermal cells lining the calicoblastic epithelium were reduced in size (atrophied), with vacuolated and uneven appearance compared with the normal tissues. A detailed SEM study of the cellular components of the tumorous tissues is in progress (Loya et al., in prep.). The calicoblastic layers and zooxanthellae densities were similar and there was no evidence of infauna or parasites in the abnormal areas. Developing oocytes were present in the samples of both the normal and tumorous areas, in 3 of the 4 colonies of $P$. pini examined in July 1981. Examination of tissue sections from boundaries between normal and abnormal areas showed complete tissue fusion, with no indications of allograft morphology. Furthermore, disturbance designed to elicit tentacular contraction resulted in a continuous wave of reaction through both abnormal and normal regions.

All colonies in the area are periodically exposed to air at spring low tides and, as a result, many have flat, dead tops (Fig. 2). The prevailing winds entering Cleveland Bay are easterly or south easterly for most of the year and an easterly swell is usually present. Nevertheless, the compass angles to which the tumors faced showed no significant grouping with respect to direction (Rayleigh-test, $\mathrm{p}>0.05$ ).

In attempts to investigate causative agents for the abnormal growth formations, we followed the regeneration rate in the experimental colonies with superficial and extensive lesions. The superficial damage was designed to represent natural damage, such as grazing activity of fishes scraping off the tissue and underlying skeletal elements (Bak \& Steward-Van Es, 1980). The extensive damage was designed to represent deep scars inflicted upon corals by corallum-feeding fish ingesting considerable amounts of $\mathrm{CaCO}_{3}$ (Randall, 1974; Neudecker, 1979), or mechanical damage caused after major storms (Collins, 1978). While complete regeneration of almost all of the superficial lesions was observed within 3 months, only a negligible proportion of the extensive lesions healed after 12 months, with the vast majority showing very low rate of regeneration (Loya et al., in prep.). Filamentous algae with trapped sediment covered the scars within 3 to 4 weeks after infliction of the lesions. We did not observe the development of abnormal growths in any of the completely regenerated lesions. 


\section{DISCUSSION}

Abnormal skeletal growths (tumors) of Platygyra pini and P. sinensis in Cockle Bay are typified by localized and increased skeletal growth. The tumors extend out of the colony's surface and differ in their morphology from surrounding normal regions (Figs $3-5)$. The X-radiographs indicate that the tumors originate in one small area of the colony (Fig. 8), presumably from a single polyp, which divides to give rise to the abnormal growth protuberance on the colony. This proliferation is independent and faster than the normal rate of skeletal growth of the surrounding coral areas (Fig, 8). Whether the faster growth of tumors described here results from nutrients drawn from nearby normal tissue, as suggested by Cheney (1975) for Acropora formosa remains to be shown. To date we have not observed any adverse effects of the tumors on the Platygyra colonies.

Although skeletal malformations have been previously described in a variety of scleractinian corals, none fall within any of Antonius's (1981a) categories of coral diseases. Antonius $(1981 \mathrm{a}, \mathrm{b})$ distinguished 4 different coral diseases: (a) "Bacterial infections": Bacteria develop on mucus secreted by the corals in response to environmental perturbation. The increased bacterial activity reduces the level of dissolved oxygen at the surface of the coral to zero, resulting in its death. (b) "Black band disease": Although the macroscopic appearance of the disease is similar (a dark band surrounding and constantly enlarging an area of denuded coral skeleton), its microbiological nature and etiology have remained largely obscure (see Antonius 1973, 1977, 1981a; Garret \& Ducklow, 1975; Ducklow \& Mitchell, 1979b). The coral tissue is destroyed at a rate of several centimeters per week. While small colonies are killed in this way within days or weeks, in large colonies the infections have a tendency to disappear. (c) "White band

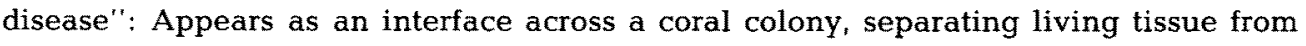
white skeleton, advancing up to several millimeters per day (no pathogen has been found yet). (d) "Shut-down reaction": A complete, spontaneous disintegration of the coral tissue, in response to considerable environmental stress.

The X-radiographs and histological sections of Platygyra from Cockle Bay have not shown any indications of infauna or parasites associated with the tumor formations. Therefore, the initiation of these abnormal growths cannot be attributed to a visible foreign agent. The possibility remains that virus or bacterial attack might have caused abnormal development. Garret \& Ducklow (1975) and Ducklow \& Mitchell (1979b) have characterized degenerative diseases of bacterial origin in scleractinian corals from the Atlantic and implicated such diseases as significant causes of coral mortality, but they did not report abnormal growth in these corals.

It is possible that the stimulus initiating the localized accelerated growth of the tumors originated from a given combination of environmental stresses possibly coupled with some sort of injury inflicted on the corals. The environmental conditions in Cockle Bay are relatively extreme with high turbidity, periodical exposure of the reef flat during spring low tides, abrupt changes in sea-water salinity during the wet season and mechanical damage to corals caused periodically but unpredictably by extensive cyclonic storm surge and wave action.

Morse et al. $(1977,1981)$ suggested that tumorigenesis in octocorals may be influenced by, or depend upon, certain environmental conditions. They reported that tumorlike growths in Gorgonia ventalina, contained an infesting filamentous green alga. The 
incidence of algal tumors in the gorgonian populations observed by the authors at Bonaire and Trinidad was highly localized and clearly non-uniform. All their observations of tumors in $G$. ventalina occurred at reefs manifestly exposed to environmental stress (e.g. highly localized storm damage or chronic exposure to conditions of low salinity and high turbidity). The highly localized occurrence of abnormal growths in Platygyra colonies at Cockle Bay and the environmental stresses encountered in this locality, closely resemble the pattern and distribution of environmental conditions reported by Morse et al. (1977) for $G$. ventalina. Morse et al. (1981) suggested that this non-uniform distribution may reflect either a dependence upon some, as yet, unidentified environmental or ecological factor(s) controlling infestation and tumorigenesis, or genetically determined differences in clonal sensitivity or resistance among populations of the gorgonian.

The series of experimental lesions inflicted on Platygyra colonies were designed to test the influence of physical injury on the rate and form of regeneration. None of the corals in the "superficial lesion" series produced abnormal growth formations, during 3 months in which they fully recovered. As noted before, filamentous algae colonized the experimental scars 3 to 4 weeks after infliction of the lesions. Phagocytic amoebocytes are known to respond to invasion of foreign material in coelenterates (Sparks, 1972) and are involved in wound repair and regeneration (Patterson \& Landolt, 1979). Furthermore, they have been implicated in morphogenetic control of tissue differentiation (Frey, 1968; in Morse et al., 1977). It is, therefore, possible that development of an aberrant polyp, giving rise to abnormal growth, may be more likely to occur during the process of tissue repair, than during normal growth of uninjured tissue. Since the "extensive lesions" had not completely healed during the 12 months of the study, it is premature to draw any conclusions on their eventual outcome.

Another possibility, although of lesser likelihood, is that the Platygyra population at Cockle Bay is genetically isolated and has the potential to produce tumors either spontaneously, by single polyp mutation, or through the action of mutagenic agent such as U.V., during low tide. Tropical regions are known to have a high incidence of neoplastic skin growth in mammals, due to the high level of U.V. irradiation (Urbach et al., 1974; Ladds \& Entwistle, 1977).

Goldberg \& Makemson (1981) reported a tumorous condition affecting the skeleton of the gorgonian coral Pseudoplexaura sp. The incidence of infected colonies, while not strictly density dependent was associated with patch reef areas where the coral densities were greater than 0.7 per $\mathrm{m}^{2}$. The tumor consisted of masses of filamentous green algae that separated the normally tightly opposed laminae of the gorgonian skeleton. The axis epithelium was found to be anaplastic and apparently disfunctional. An abnormal proliferation of mesogleal amoebocytes and axial stem canals was also noted. The authors indicated that larger Pseudoplexaura colonies ( $>80 \mathrm{~cm}$ high) are 2.5 times as likely to possess tumors as smaller individuals.

Recently, Bak (1983) reported an abnormal process of calcification, such as regenerating lesions and neoplasia situated near the tips of colonies of Acropora palmata, which suppressed normal linear growth. Branches having neoplasia at a larger distance than $25 \mathrm{~cm}$ from the tip did not grow significantly differently from controls. He interpreted this as indication of a functional minimal area terms of energy supply.

The relationship between size (mean colony diameter) and likelihood of possessing 
tumors is of interest, since size is most probably correlated with age, as shown for other scleractinian corals (Loya, 1976b). The Platygyra colonies at Cockle Bay were the largest we have encountered amongst populations of high abundance, on the reef flats of the Great Barrier Reef (Fig. 2). Some colonies were up to $120 \mathrm{~cm}$ in diameter. The incidence of abnormal growths within populations of both $P$. pini and $P$. sinensis is at least 7 times higher in older colonies $(>80 \mathrm{~cm}$ in diameter) than in younger colonies $(<40 \mathrm{~cm}$ in diameter). This may explain the low occurrence, or almost complete absence of such abnormal growths in other localities in the vicinity of Magnetic Island or other reef flats on the Great Barrier Reef, where the vast majority of Platygyra colonies are very small. It is logical to assume that older colonies have had a higher chance of encountering the exact combination of environmental conditions inductive to the development of such tumors. Furthermore, larger colonies are exposed for longer periods of time during spring low tides, hence they produce large amounts of mucus as a protective layer. An increased rate of mucus production also occurs in response to sedimentation or high turbidity (Hubbard \& Pocock, 1972; Loya, 1976a; Dodge \& Vaisnys, 1977), which are environmental stresses that typify Cockle Bay. Ducklow \& Mitchell (1979a) indicated that bacterial populations in coral mucus respond to stresses applied to the host coral by higher population levels in the mucus. It still remains to be shown whether specific bacteria develop on the mucus secreted by Platygyra, which might cause local damage (death) of part of the colony and induce development of abnormal growth, during the regeneration process of the tissue.

Acknowledgements. We are grateful to C. Wilkinson, C. Wallace, and I. Paperna for their helpful comments on the manuscript and especially to P. Yevich and E. Peters for their help with the histopathological interpretation of the samples. Y. L. is indebted to the Queen Elizabeth Fellowship Committee for financial support during his stay in Australia as a Senior Queen's Fellow and to the Australian Institute of Marine Science and James Cook University of North Queensland for hospitality and providing facilities.

\section{LITERATURE CITED}

Antonius, A., 1973. New observations on coral destruction in reefs. - Meet. Ass. Isl. Mar. Lab. Caribb., Univ. Puerto Rico, Mayaguez 10, 3 (abstract).

Antonius, A., 1977. Coral mortality in reefs: A problem for science and management. - Proc. 3rd int. Coral Reef Symp., Miami, 2, 618-623.

Antonius, A., 1981 a. Coral reef pathology: A review. - Proc. 4th int. Coral Reef Symp. Manila 2, 3-6.

Antonius, A., 1981b. The "band" diseases in coral reefs. - Proc. 4th int. Coral Reef Symp. Manila 2, $7-14$.

Bak, R. P. M. \& Steward-Van Es, Y., 1980. Regeneration of superficial damage in the scleractinian corals Agaricia agaricites f. purpurea and Porites astreoides, - Bull. mar. Sci. 30, 883-887.

Bak, R. P. M., 1983. Neoplasia, regeneration and growth in the reef-building coral Acropora palmata. - Mar. Biol. 77, 221-227.

Bull, G. D., 1982. Scleractinian coral communities of two inshore high island fringing reefs at Magnetic Island, North Queensland. - Mar. Ecol. Prog. Ser. 7, 267-272.

Cheney, D. P., 1975. Hard tissue tumors in scleractinian corals. - Adv. exp. Med. Biol. 64, 77-87.

Cheng, T. C. \& Wong, A. K. L., 1974. Chemical, histochemical and histopathological studies on coral Porites spp. parasitized by trematode metacercariae, - J. Invertebr. Pathol. 23, 303-317.

Collins, J. D., 1978. A study of the interactive biology of corals. Ph. D. Thesis, James Cook Univ, of North Queensland, Townsville, $182 \mathrm{pp}$.

Dodge, R. E. \& Vaisnys, J. R., 1977. Coral populations and growth patterns: responses to sedimentation and turbidity associated with dredging. - J. mar. Res. 35, 715-730. 
Ducklow, W. H. \& Mitchell, R., 1979a. Bacterial populations and adaptations in the mucus layers on living corals. - Limnol. Oceanogr. 24, 715-725.

Ducklow, W. H. \& Mitchell, R., 1979b. Observations on naturally and artificially diseased tropical corals: a scanning electron microscope study. - Microb. Ecol. 5, 215-223.

Garrett, P. \& Ducklow, H., 1975. Coral diseases in Bermuda. - Nature, Lond. 253, 349-350.

Goldberg, W. M. \& Makemson, $J, 1981$. Description of a tumorous condition in a gorgonian coral associated with a filamentous green alga, - Proc. 4th int. Coral Reef Symp., Manila, 2, 685-697.

Grigg, H., 1972. The taxonomy and distribution of Pseudodiaptomus (Copepoda, Calanoida) in the Townsville region. M. Sc. Thesis, James Cook Univ. of North Queensland, Townsville, $172 \mathrm{pp}$.

Hildemann, W. H., Linthicum, D. S. \& Vann, D. C. 1975 . Immunoincompatibility reactions in corals (Coelenterata). - Adv. exp. Med. Biol. 64, 105-114.

Hubbard, J, A. \& Pocock, Y. P., 1972. Sediment rejection by recent scleractinian corals: A key to paleoenvironmental reconstruction. - Geol. Rdsch. 61, 598-626.

Isdale, P., 1977. Variations in growth rate of hermatypic corals in a uniform environment. - Proc. 3rd int. Coral Reef Symp., Miami, 2, 403-408.

Kaufman, L. S., 1980. Damselfish disturbance on Caribbean coral reefs. Ph. D. Thesis, John Hopkins Univ., Baltimore, Md., 139 pp.

Kenny, R. P., 1974. Inshore surface sea temperatures at Townsville. - Aust. J. mar. Freshwat. Res. 25, $1-5$.

Ladds, P. W. \& Entwistle, K. W., 1977. Observations on squamous cell carcinomas of sheep in Queensland, Australia. - Br. J. Cancer 35, 110-114.

Loya, Y., 1976 a. Effects of water turbidity and sedimentation on the community structure of Puerto Rican corals. - Bull. mar. Sci. 26, 450-466.

Loya, Y., 1976b. The Red Sea coral Stylophora pistillata is an r-strategist. - Nature, Lond. 259, $478-480$.

Morrissey, $J, 1980$. Community structure and zonation of macroalgae and hermatypic corals on a fringing reef flat of Magnetic Island (Queensland, Australia). - Aquat. Bot. 8, 91-139.

Morse, D. E., Morse, A. N. C. \& Duncan, H., 1977. Algal "tumors" in the Caribbean sea-fan, Gorgonia ventalina. - Proc. 3rd int. Coral Reef Symp. Miami, 1, 623-629.

Morse, D. E. \& Trench, R. K., 1981. Algal tumors in the Caribbean octocorallian Gorgonia ventalina: II. Biochemical characterization of the algae, and first epidemiological observations. - Bull. mar. Sci. 31, 399-409.

Neudecker, S., 1979. Effects of grazing and browsing fishes on the zonation of corals in Guam. Ecology 60, 666-672.

Patterson, M. H. \& Landolt, M. L., 1979. Cellular reaction to injury in the anthozoan Anthopleura elegatissima. - J. Invertebr. Pathol. 33, 189-196.

Patton, W. K., 1976. Animal associates of living reef corals. In: Biology and geology of coral reefs. Ed. by O. A. Jones \& R. Endean. Acad. Press, New York 3, 1-36.

Randall, J. E., 1974. The effect of fishes on coral reefs. In: Proceedings of the 2nd international Symposium on coral reefs. Great Barrier Reef Comm., Brisbane, 1, 159-166.

Rinkevich, B. \& Loya, Y., 1977. Harmful effects of chronic oil pollution on a Red Sea scleractinian coral population. - Proc. 3rd int. Coral Reef Symp. Miami, 1, 585-591.

Soule, J. D., 1965. Abnormal corallites. - Science, N. Y. 150, 78.

Sparks, A. K., 1972. Invertebrate pathology, noncommunicable diseases. Acad. Press, New York, $387 \mathrm{pp}$.

Squires, D. F., 1965a. Neoplasia in a coral? - Science, N. Y. 148, 503-505.

Squires, D. F., 1965b. Abnormal corallites. - Science, N. Y. 150, 78.

Urbach, F., Epstein, J. H. \& Forbes, P. D., 1974. Ultraviolet carcinogenesis: Experimental, global, and genetic aspects. In: Proceedings of the international conference on photosensitization and photoprotection. Ed. by T. B. Fitzpatrick, M. A. Pathak, L. C. Harber, M. S. Seiji \& A. Kukita. Univ. of Tokyo Press, Tokyo, 259-283.

Veron, J. E. N., Pichon, M. \& Wijsman-Best, M., 1977. Scleractinia of Eastern Australia. Part II. Families Faviidae, Trachyphyllidae. Aust, Gov, Publ. Service, Canberra, 233 pp.

White, P. R., 1965. Abnormal corallites. - Science, N. Y. 150, 77-78. 